Battling Bella 



\title{
Battling Bella
}

\section{THE PROTEST POLITICS OF BELLA ABZUG}

\section{Leandra Ruth Zarnow}

\author{
III \\ III \\ Harvard University Press \\ CAMBRIDGE, MASSACHUSETTS \\ LONDON, ENGLAND \\ 2019
}


Copyright @ 2019 by Leandra Ruth Zarnow

All rights reserved

Printed in the United States of America

First printing

Jacket photo: Ron Galella / Getty Images

Jacket design: Jill Breitbarth

9780674243767 (EPUB)

9780674243774 (MOBI)

9780674243750 (PDF)

Publication of this book has been supported through the generous provisions of the Maurice and Lula Bradley Smith Memorial Fund.

The Library of Congress has cataloged the printed edition as follows:

Names: Zarnow, Leandra Ruth, 1979- author.

Title: Battling Bella : the protest politics of Bella Abzug /

Leandra Ruth Zarnow.

Description: Cambridge, Massachusetts : Harvard University Press, [2019] I

Includes bibliographical references and index.

Identifiers: LCCN 2019014313 I ISBN 9780674737488 (alk. paper)

Subjects: LCSH: Abzug, Bella S., 1920-1998. I Women—Political

activity-United States-History-20th century. I Civil rights

movements-United States-History-20th century. I Democratic

Party (U.S.) I United States-Politics and government-20th century.

Classification: LCC E840.8.A2 Z37 2019 | DDC 320.082/0973—dc23

LC record available at https://lccn.loc.gov/2019014313 
For my parents, boundless believers.

And Juan Cisneros, for whom New York's

city lights dimmed too soon. 
